\title{
Analisis Perlindungan Hukum Terhadap Peserta Lelang dalam Pelaksanaan Eksekusi Hak Tanggungan oleh Pihak Bank
}

\author{
Nurlaily $^{1}$, Triana Dewi Seroja ${ }^{2}$, Winda Fitri ${ }^{3}$, dan Zaiqui Arviveronica Fimos ${ }^{4}$ \\ ${ }^{1,2,3,4}$ Fakultas Hukum, Universitas Internasional Batam \\ Corresponding author. Email: drnurlaly@uib.ac.id
}

Naskah diterima: 23-10-2020; revisi: 07-12-2020; disetujui: 16-12-2020

DOI: https://doi.org/10.46257/jrh.v24i2.140

\begin{abstract}
Abstrak
Bank sebagai lembaga penyaluran dana kepada masyarakat juga memerlukan jaminan atas dana yang disalurkan tersebut, salah satu jaminan yang dapat diagunkan adalah Sertifikat Hak Atas Tanah, yang kemudian dibebankan Hak Tanggungan agar memiliki Hak Eksekutorial sebagaimana diatur dalam UU No. 4 Tahun 1996 tentang Hak Tanggungan yang mana salah satu cara eksekusi Hak Tanggungan adalah dengan cara proses lelang yang diatur secara khusus dalam PMK No. 27/PMK.06/2016 tentang Petunjuk Pelaksanaan Lelang. Penelitian ini dilakukan dikarenakan pemberlakuan peraturan hak tanggungan masih belum maksimal atau masih menimbulkan permasalahan baik bagi pihak kreditur dan peserta lelang. Tujuan penelitian ini dilakukan adalah untuk menganalisis permasalahan hukum yang timbul dalam pelaksanaan eksekusi hak tanggungan, serta permasalahan yang dihadapi oleh pihak Bank setelah proses pelaksanaan lelang dilakukan, serta untuk menganalisis perlindungan hukum bagi peserta lelang yang telah beritikad baik dalam proses lelang ditinjau dari UU No. 4 Tahun 1996 tentang Hak Tanggungan Atas Tanah dan Peraturan Menteri Keuangan No. 27/PMK.06/2016 tentang Petunjuk Pelaksanaan Lelang. Dengan pendekatan penelitian normative empiris dan spesifikasi deskriptif analisis didapatkan bahwa banyak debitur yang mengajukan perlawanan ketika pihak Bank hendak melakukan eksekusi Hak Tanggungan, sehingga mengakibatkan pihak Bank tidak dapat menggunakan hak eksekutorial, melainkan harus mengajukan Penetapan Pengadilan. Peraturan yang berlaku masih tidak mengatur secara rinci dan khusus terkait perlindungan hukum terhadap kreditur serta peserta lelang yang telah beritikad baik.
\end{abstract}

Kata kunci: eksekusi hak tanggungan, bank, lelang, perlindungan hukum.

\section{Analysis of Legal Protection Against Auction Participants in the Execution of Underwriting Rights by the Bank}

\begin{abstract}
The Bank as a fund-raising agency to the public also needs collateral for the disbursed funds, one of the collateral guarantees is the certificate of lands, which is then subject to the Underwriting Rights in order to have the rights of executorial as stipulated in Law No. 4 of 1996 concerning the Underwriting Rights to land and objects relating to land where one of the means of execution of Underwriting Rights is by means of an auction process specifically stipulated
\end{abstract}


in regulation of the Minister of Finance No. 27/PMK.06/2016 about the auction's implementation instructions. Reseachers do this research because the implementation of the Regulation still not yet provide maximum or still cause problems for the creditors and the auction participants. The purpose of this research is to analyze legal problems that arise in the execution of mortgage rights, as well as problems faced by the Bank after the auction process is carried out, as well as to analyze legal protection for auction participants who have had good intentions in the auction process in terms of Law No. 4 of 1996 concerning the Underwriting Rights to land and Regulation of the Minister of Finance No. 27/PMK.06/2016 about the auction's implementation instructions. With an empirical normative research approach and descriptive analysis specification got that there are debtors filed a resistance when the Bank want to execute the Underwriting Rights, which the effect was Bank couldn't to use the Executorial Rights, but have to file a Court Order. Applicable regulation still not regulated in detail and specifically regarding legal protection for creditors and auction participants who have been in good faith.

Keywords: execution of underwriting rights, banks, auctions, legal protection.

\section{Pendahuluan}

Tujuan pembangunan hukum melalui kepastian peraturan perundangan sangat diperlukan terutama dalam menunjang pembagunan dalam bidang ekonomi yang dewasa ini berkembang sangat pesat. Salah satu sarana hukum yang dapat menunjang perkembangan bidang ekonomi tersebut adalah perangkat lembaga hukum jaminan. Hukum Jaminan merupakan sarana yang dibutuhkan dalam pembangunan secara fisik, terutama kaitannya dengan perjanjian kredit perbankan. Pembangunan secara fisik mutlak memerlukan dana yang cukup, salah satu cara perolehan dana yang dilakukan adalah melalui jasa perbankan, yaitu melalui kredit yang diberikan oleh lembaga bank.

Layanan perbankan yang diselenggarakan kini menawarkan berbagai kemudahan yang dapat dimanfaatkan masyarakat setiap saat dan dimana saja salah satunya melalui penggunaan teknologi dengan sistem online. Dalam pengajuan kreditnya juga lebih mudah karena persyaratan yang diperlukan bersifat umum dan tidak berbelit-belit dan tidak memerlukan waktu yang banyak apabila debitur yang mengajukan kredit tidak memiliki riwayat pinjaman yang buruk, serta apabila dari segi dokumen dilengkapi dengan cepat, maka 
proses pencairan dana dapat dilakukan dalam waktu singkat juga (Nevita Sari, 2019: 149-168)

Bank dalam memberikan pinjaman atau kredit kepada debitur cenderung meminta jaminan kebendaan berupa hak tanggungan yang diletakkan dalam isi perjanjian kredit. Hal ini dikarenakan jaminan kebendaan merupakan hak mutlak atas suatu benda tertentu yang dijadikan objek jaminan untuk suatu ketika dapat diuangkan bagi pelunasan ataupun pembayaran hutang bila debitur melakukan wanprestasi. Salah satu benda yang sering dipakai sebagai jaminan adalah Tanah. Penggunaan hak atas tanah sebagai agunan cenderung dipraktekkan dalam kredit untuk berbagai keperluan, termasuk untuk keperluan pembangunan, karena tanah dianggap paling aman untuk dijadikan jaminan (Evie Christy dkk, 2020: 323-344).

Kepastian hukum dan perlindungan hukum diperlukan guna untuk memberikan jaminan hak-hak para pihak serta agar tata tertib dalam melaksanakan kegiatan ekonomi berupa penyaluran dana oleh Bank serta pemberian jaminan hak tanggungan bisa berjalan dengan baik, maka dibentuk sebuah payung hukum yaitu Undang-Undang Nomor 4 Tahun 1996 tentang Hak Tanggungan Atas Tanah Beserta Benda-Benda Yang Berkaitan Dengan Tanah yang selanjutnya Peneliti sebut sebagai UU No.4 Tahun 1996.

Hak Tangungan yang diatur hanya dapat dibebankan pada hak atas tanah dan juga benda-benda yang terdapat diatasnya, contoh seperti gedung-gedung, tanaman, dan juga hasil lainnya yang termasuk dalam satu kesatuan dengan tanah tersebut, dan kemudian dijadikan sebagai jaminan. Dalam Pasal 4 Ayat (1) UU No.4 Tahun 1996 juga menyebutkan bahwa hak atas tanah yang dapat dibebani dengan Hak Tanggungan yaitu Hak-Milik, Hak Guna Usaha, Hak Guna Bangunan.

Dalam hal ini Hak Tanggungan tidak bisa berdiri sendiri tanpa adanya dukungan oleh suatu perjanjian antara debitur dan kreditur, Setelah perjanjian pinjam meminjam disepakati, maka lahirlah hak dan kewajiban antara kedua belah pihak (kreditur dan debitur). Apabila dalam perjanjian pinjam-meminjam, debitur tidak memenuhi kewajibannya membayar hutang sesuai dengan 
kesepakatan dan jangka waktu yang disepakati maka debitur dinyatakan wanprestasi. Sebagaimana dimaksud dalam Pasal 6 UU No. 4 Tahun 1996 merupakan salah satu perwujudan dari kedudukan yang dipunyai kreditur sebagai pemegang hak tanggungan. Apabila debitur wanprestasi maka pemegang hak tanggungan berhak untuk menjual objek hak tanggungan melalui pelelangan umum tanpa diperlukan persetujuan dari pemberi hak tanggungan.

Pada dasarnya perjanjian antara pihak kreditur dan debitur dengan hak tanggungan tidaklain bertujuan untuk bisa memperlancar eksekusi benda jaminan hak atas tanah dalam proses pengembalian piutang kreditur oleh debitur. Eksekusi hak tanggungan adalah sarana untuk mempercepat proses pengembalian hutang dari debitur.

Jaminan Hak Tanggungan dalam hal dana yang disalurkan yang dilakukan oleh pihak Bank kepada debitur, memiliki tujuan guna memberikan perlindungan hukum bagi pihak Bank jika ke depannya timbul wanprestasi atas isi dari perjanjian kredit yang telah disepakati antara pihak debitur dan pihak Bank, dan juga untuk memberikan kedudukan yang diutamakan terhadap Bank. Apabila ke depannya pihak debitur wanprestasi sehingga mengakibatkan kredit macet, maka Bank berhak atas eksekusi yang didasari atas hak eksekutorial dari jaminan Hak Tanggungan, dikarenakan pihak Bank juga berhak atas perlindungan hukum, dan pihak Bank juga tentu tidak ingin dirugikan atas asas itikad baik yang telah dilakukan.

Bank melakukan eksekusi karena memiliki hak eksekutorial, yang mana kedudukan eksekusi adalah setara atau sama dengan inkrah dari putusan Pengadilan oleh karena dalam jaminan Hak Tanggungan tercantumkan irah-irah "Demi Keadilan Berdasarkan Ketuhanan Yang Maha Esa". Namun walaupun Bank memiliki hak untuk eksekusi, jaminan yang dibebankan dengan Hak Tanggungan, kendala pelaksanaan eksekusi Hak Tanggungan masih sering terjadi, yang mana pada prakteknya kendala yang sering terjadi adalah pihak debitur yang telah wanprestasi dan tidak dapat melakukan pelunasan hutangnya, tidak bersedia atau tidak melakukan pengosongan objek Hak Tanggungan secara 
sukarela dan bersikeras ingin mempertahankan objek jaminan sehingga pada akhirnya permohonan pengosongan objek jaminan harus dilakukan.

Pelaksanaan eksekusi Hak Tanggungan juga tidak menutup kemungkinan akan terjadinya gugatan dari pihak ketiga terhadap objek jaminan tersebut, yang mana hal tersebut dikarenakan pihak ketiga merasa dirugikan apabila objek jaminan tersebut dieksekusi oleh pihak Bank. Apabila objek jaminan yang dieksekusi dengan cara penetapan lelang oleh Pengadilan Negeri dan telah mendapatkan pembeli atau peserta lelang atas jaminan tersebut, maka pihak pembeli akan sangat dirugikan dikarenakan gugatan pihak ketiga yang masuk tersebut mengakibatkan pembeli tidak dapat menguasai jaminan tersebut hingga mendapatkan Putusan yang Inkracht akan gugatan pihak ketiga.

Kendala-kendala yang terjadi memberikan akibat hukum yang tidak pasti terhadap jaminan yang telah dibebankan Hak Tanggungan dan telah diatur secara khusus dalam UU Hak Tanggungan. Akibat terjadinya kendala tersebut, memberikan akibat pada pihak Bank yakni mengalami kerugian dan mengakibatkan timbulnya ketidaknyamanan terhadap calon pembeli yang telah beritikad baik ingin membeli objek jaminan tersebut jika debitur sebelumnya masih menguasai objek jaminan atau masih tinggal di rumah yang merupakan objek eksekusi Hak Tanggungan.

Kendala-kendala sebagaimana disebutkan diatas tetap sering terjadi walaupun pelaksanaan lelang yang dilakukan tidak hanya berlandaskan pada UU tentang Hak Tanggungan, namun juga telah diatur Peraturan yang bersifat khusus, seperti "Peraturan Menteri Keuangan Nomor 27/PMK.06/2016 tentang Petunjuk Pelaksanaan Lelang" yang selanjutnya disebut PMK No. 27/PMK.06/2016, sehingga Peneliti ingin meneliti tentang permasalahan hukum yang timbul dalam pelaksanaan lelang oleh Bank berlandaskan pada "PMK No. 27/PMK.06/2016", hal-hal yang dihadapi oleh pihak Bank dalam pelaksanaan lelang maupun pihak pembeli Lelang, serta perlindungan hukum bagi pihak pembeli yang telah beritikad baik untuk membeli objek lelang namun menghadapi masalah hukum sebagaimana dijelaskan diatas. 
Berdasarkan latar belakang di atas, maka Peneliti merumuskan permasalahan yang terjadi menjadi tiga rumusan masalah yaitu sebagai berikut:

a. Apakah permasalahan hukum yang timbul dalam pelaksanaan eksekusi hak tanggungan di dalam Peraturan Menteri Keuangan No. 27/PMK.06/2016 tentang Petunjuk Pelaksanaan Lelang?

b. Apa saja permasalahan yang dihadapi oleh pihak Bank setelah proses pelaksanaan lelang dilakukan?

c. Bagaimana perlindungan hukum bagi peserta lelang yang telah beritikad baik dalam proses lelang ditinjau dari UU No. 4 Tahun 1996 tentang Hak Tanggungan Atas Tanah dan PMK No. 27/PMK.06/2016 tentang Petunjuk Pelaksanaan Lelang?

Penelitian ini menggunakan metode penelitian normative empiris yaitu mengkaji ketentuan hukum yang berlaku serta apa yang terjadi dalam kenyataan dimasyarakat (Jonaedi Efendi, 2016: 148).

Penelitian yang terjadi atau dilakukan di lapangan atau data yang diperoleh langsung dari masyarakat sebagai sumber pertama dengan melalui penelitian lapangan, yang dilakukan baik melalui. Obyek penelitian yang Peneliti gunakan dalam melakukan penelitian empiris adalah dengan menggunakan data primer yang mana diperoleh dari hasil pengamatan (observasi), wawancara, ataupun dengan cara penyebaran kuesioner terkait permasalahan yang sedang terjadi di lapangan yang mana tempat dijadikan objek penelitian adalah Kantor Pelayanan Kekayaan Negara dan Lelang (selanjutnya disebut dengan KPKNL) di Kota Batam. Adapun data sekunder yang Peneliti gunakan sebagai data pendukung yakni terdiri atas bahan hukum primer dan sekunder. Metode analisis data yang digunakan dalam melakukan penelitian ini adalah dengan menggunakan analisis data kualitatif.

\section{Pembahasan}

\section{A. Permasalahan Hukum yang Timbul Dalam Pelaksanaan Eksekusi Hak Tanggungan di dalam Peraturan Menteri Keuangan No. 27/PMK.06/ 2016 tentang Petunjuk Pelaksanaan Lelang.}


Proses penjualan melalui proses lelang diatur secara khusus dalam Peraturan Menteri Keuangan No. 27/PMK.06/2016. Proses pelaksanaan lelang yang telah diatur secara khusus dalam PMK No. 27/PMK.06/2016 seharusnya telah dapat menjamin perlindungan hukum bagi pihak-pihak yang melaksanakan proses lelang sesuai dengan aturan yang berlaku. Namun permasalahan hukum masih terjadi, dimana masih adanya kerugian yang timbul bagi pihak-pihak terkait seperti pihak kreditur dan peserta lelang apabila adanya timbul gugatan dari pihak ketiga terhadap objek lelang, sehingga tidak adanya perlindungan hukum bagi pihak kreditur dan peserta lelang.

Pelaksanaan lelang sendiri oleh pihak kreditur dapat dilaksanakan secara langsung melalui Balai Lelang, yang mana dalam hal ini dapat diajukan langsung ke KPKNL dikarenakan pihak kreditur memilik hak eksekutorial apabila hak atas tanah debitur telah dibebankan Hak Tanggungan dan dinilai tidak akan terjadi sengketa dalam pelaksanaan proses lelang dan juga dapat melalui Penetapan Pengadilan apabila debitur dinilai tidak memiliki itikad yang baik atau dinilai akan terjadi sengketa dikemudian hari.

Berdasarkan Pasal 14 Ayat (1) PMK No. 27/PMK.06/2016 yang menyatakan bahwa "Dalam hal terdapat gugatan sebelum pelaksanaan lelang terhadap objek Hak Tanggungan dari pihak lain selain debitor/tereksekusi, suami atau istri debitor/ tereksekusi yang terkait kepemilikan, Lelang Eksekusi Pasal 6 UUHT tidak dapat dilaksanakan". Apabila terdapat gugatan ketika hendak melaksanakan lelang terhadap objek Hak Tanggungan, maka pelaksanaan lelang harus didahulukan dengan pengajuan permohonan ke Pengadilan Negeri sebagaimana diatur dalam Pasal 14 Ayat (3) PMK No. 27/PMK.06/2016 yang menyatakan bahwa "Permohonan atas pelaksanaan lelang sebagaimana dimaksud pada Ayat (2) dilakukan oleh Pengadilan Negeri, kecuali jika pemegang Hak Tanggungan merupakan lembaga yang menggunakan sistem syariah maka permohonan dilakukan oleh Pengadilan Agama”. Permohonan ke Pengadilan Negeri untuk pelaksanaan lelang pada prakteknya telah dilakukan oleh kreditur apabila kreditur menilai akan terjadi sengketa walaupun bukan berupa gugatan dari pihak lain namun pada 
prakteknya masih terdapat debitur nakal yang tidak bersedia untuk mengikuti langkah yang diberikan oleh kreditur, atau tetap bersikeras untuk tinggal di objek Hak Tanggungan tersebut sehingga kreditur harus menempuh langkah mengajukan permohonan hingga proses pengosongan objek Hak Tanggungan tersebut.

Berdasarkan hasil wawancara peneliti dengan Bapak Jumianto, bagian legal dari BPR Duta Kepri Kota Tanjungpinang terkait dengan pelaksanaan eksekusi hak tanggungan yang dilaksanakan oleh BPR Duta Kepri. Pernyataan dari beliau bahwa pelaksanaan eksekusi Hak Tanggungan dilakukan melalui proses lelang berdasarkan hak eksekutorial yang dimiliki oleh Bank dikarenakan akan menghabiskan waktu dan biaya apabila dilakukan melalui Penetapan Pengadilan. Selain itu, pihak Bank juga telah memberikan Surat Peringatan 1 (satu) hingga 3 (tiga) dan juga surat panggilan juga dilayangkan sebelum pihak Bank melakukan eksekusi Hak Tanggungan, namun pihak debitur masih tidak ingin melakukan penyerahan atau tidak adanya itikad baik untuk menandatangani akta penyerahan jaminan dan akta kuasa menjual kepada Bank sehingga eksekusi Hak Tanggungan melalui proses lelang ddilakukan. Surat Peringatan pertama dilayangkan dengan dirincikan total angsuran, bunga, dan denda serta dilampirkan batas waktu untuk melakukan pembayaran. Apabila Surat Peringatan pertama tidak ditanggapi, maka akan dilayangkan Surat Peringatan kedua begitu selanjutnya hingga Surat Peringatan ketiga dari pihak kreditur kepada pihak debitur. Debitur yang tidak menanggapi atau tidak memiliki itikad baik akan dilanjutkan ke kuasa hukum kreditur yang terkait yakni somasi pertama yang dilayangkan guna untuk memberikan peringatan kepada pihak debitur dengan harapan debitur tetap memiliki itikad baik dan akan melakukan pembayaran angsuran. (Jumianto: Hasil Wawancara, 2020).

Ketidakhadiran pihak debitur setelah adanya panggilan dari Pengadilan sebanyak 3 (tiga) kali, maka akan gugur haknya untuk panggilan selanjutnya, dan pihak Pengadilan akan memutus dengan menerbitkan penetapan eksekusi yang ditujukan pada Panitera/Jurusita yang kemudian dilanjutkan ke proses pelelangan, yakni ke KPKNL Kota Batam dengan berlandaskan pada Surat 
Penetapan Pengadilan tersebut. Proses lelang dilakukan seperti pada umumnya, dan apabila telah mendapatkan peserta lelang namun debitur masih menempati objek Hak Tanggungan tersebut, maka langkah selanjutnya adalah dengan cara mengajukan permohonan pencabutan sita eksekusi dan pengosongan objek Hak Tanggungan yang wajib dilaksanakan dalam kurun waktu yang telah ditentukan.

Dalam PMK No. 27/PMK.06/2016 mengatur apabila terjadi gugatan dari debitur atau pihak lain sebagaimana diatur dalam Pasal 14 Ayat (1) sebelum dilaksanakan proses lelang namun permasalahan yang Peneliti teliti sekarang adalah terkait dengan gugatan yang muncul setelah pelaksanaan lelang telah dilakukan, yang mana peserta lelang menjadi pihak yang dirugikan dan tidak ada perlindungan hukum terhadap peserta lelang yang telah memiliki itikad baik untuk melakukan pembelian objek Hak Tanggungan tersebut. Sengketa terjadi karena adanya gugatan dari pihak ketiga yang menyatakan bahwa hak atas tanah yang menjadi objek Hak Tanggungan merupakan hak atas tanah tersebut juga merupakan miliknya dan merasa dirugikan dikarenakan adanya itikad tidak baik dari pihak debitur diawal dilakukannya perjanjian kredit dengan pihak kreditur.

Putusan Nomor 92/Pdt.G/2017/PN.Btm pada tanggal 20 Desember 2017 memutus dikabulkan sebagian terhadap gugatan yang diajukan oleh pihak ketiga terkait dengan objek Hak Tanggungan yang telah dilaksanakan melalui proses lelang dan memutus batal demi hukum lelang eksekusi yang dilaksanakan berdasarkan Risalah Lelang No. 001/2017, tanggal 03 Januari 017, beserta semua akibat hukumnya. Menurut analisa hukum Peneliti, terkait dengan permasalahan putusan Hakim diatas masih diperlukan pembaharuan peraturan guna untuk melindungi hak dari kreditur atau peserta lelang. Karena berdasarkan hasil penyebaran Kuesioner peneliti kepada masyarakat sebanyak 85,1\% dari 296 Responden menjawab merasa dirugikan atas proses permohonan ke Pengadilan terhadap objek lelang yang masih ditempatati pihak ketiga dan/atau ada tuntutan pihak ketiga. Oleh sebab itu, peserta lelang harus mengeluarkan biaya, dan objek Hak Tanggungan tidak dapat ditempati oleh peserta lelang yang telah beritikad baik untuk membeli objek Hak Tanggungan tersebut. Menurut pendapat dari Ibu Eka Gusriani Aryanti, Pimpinan Cabang PT BPR 
Central Kepri yang menghadapi permasalahan gugatan dari pihak ketiga, seharusnya terdapat aturan khusus yang menyatakan bahwa objek Hak Tanggungan saat akan dieksekusi harus dalam keadaan kosong, karena gugatan dari pihak ketiga dapat muncul saat diajukan permohonan pengosongan objek Hak Tanggungan ketika risalah lelang sudah terbit, dikarenakan dalam hal ini pihak Bank juga merasa dirugikan baik dari segi biaya dan waktu. Pihak Bank juga berada diposisi yang hanya dapat mengikuti proses karena apabila pihak debitur wanprestasi dan apabila pihak Bank tidak melakukan tindakan lebih lanjut, maka penilaian terhadap Bank yang bersangkutan juga akan menurun dan Bank dipandang tidak mencari solusi terhadap permasalahan yang terjadi. Sehingga sangat diperlukan peraturan lebih lanjut yang mengatur lebih khusus tentang pelaksanaan eksekusi Hak Tanggungan agar perlindungan hukum bagi pihak Bank dan pemenang lelang juga lebih terjamin. (Eka Gusriani Aryanti: Wawancara, 2020).

Peneliti telah mengumpulkan data primer dari hasil penyebaran kuesioner secara online pada tanggal 13-16 Agustus di Batam. Dari hasil penyebaran kuesioner sebanyak 296 (dua ratus sembilan puluh enam) responden yang menjawab yang peneliti ambil sampling nya, Responden didominasi oleh kalangan muda dibawah 30 tahun, dimana dari 296 responden dengan Usia 1830 tahun sebanyak 61,8\% dan usia 31-40 tahun keatas sebanyak 38,2\%. Kategori Pekerjaan dari responden adalah dari Karyawan Swasta (30\% responden), Pengusaha (23\% responden), Pegawai Negeri (10\% responden), Mahasiswa (14\% responden), Pegawai Negeri (12\% responden), Ibu Rumah Tangga (5\% responden) dan pensiunan (5\% responden). Dengan kesimpulan bahwa pekerjaan responden yang peneliti wawancara berasal dari Pegawai Swasta di Batam. Dari 296 responden tersebut sebanyak 88,9\% dari responden mengetahui tentang lelang yang diketahui dari berbagai sumber. Alasan atau landasan para responden ingin membeli objek tanah atau objek Hak Tanggungan melalui lelang sebanyak 64,2\% dari responden memilih karena harga objek lelang lebih murah dari harga pasaran dan sebanyak $78 \%$ responden mengetahui 
bahwa lelang dapat dilaksanakan secara online sehingga untuk mengikuti bidding akan jauh lebih mudah.

Meskipun demikian, apabila terjadi permasalahan yakni objek Hak Tanggungan yang dilelang masih ditempati oleh debitur ataupun pihak ketiga atau tidak dalam keadaan kosong, yang mana sebanyak 55,7\% responden menyatakan bahwa akan mengajukan permohonan pengosongan rumah ke Pengadilan Negeri, namun sebanyak $85,1 \%$ responden menjawab merasa dirugikan atas proses permohonan pengosongan rumah ke Pengadilan terhadap objek lelang dan atas perihal demikian, sebanyak 51,4\% responden menjadi ragu dan tidak yakin akan menjadi peserta lelang untuk ke depannya, dan sebanyak $27,4 \%$ respon menjawab tidak ingin mengikuti proses jual beli melalui lelang lagi untuk ke depannya. Persentase penyalahan terhadap Bank atas permasalahan yang dihadapi masih cukup tinggi yakni sebanyak 78,7\% meskipun permasalahan yang terjadi juga merupakan hal yang tidak diinginkan oleh pihak Bank.

PMK No. 27/PMK.06/2016 dibuat guna untuk rakyat Indonesia agar proses pelaksanaan lelang dapat dilaksanakan secara adil dan dapat membawa kesejahteraan kepada masyarakat. Namun, berdasarkan teori hukum Perlindungan Hukum, Peneliti menilai bahwa walaupun peraturan tersebut telah mengatur tentang pelaksanaan lelang, namun masih belum dapat melindungi rakyat sepenuhnya dalam hal ini adalah pihak peserta lelang. Peserta lelang yang telah memiliki itikad baik, dikarenakan terjadinya permasalahan atau sengketa mengakibatkan peserta lelang mengalami kerugian dari segi waktu dan biaya.

Teori Perlindungan Hukum juga menyatakan bahwa permasalahan yang timbul dan memiliki kaitan dengan hukum, seharusnya hukum yang diberlakukan dapat memberikan perlindungan hukum guna untuk mencapai keadilan sehingga peraturan yang mengatur tentang pelaksanaan lelang menurut Peneliti perlu diatur lebih rinci terkait perlindungan hukum yang dapat diberikan kepada peserta lelang berlandaskan pada teori Perlindungan Hukum menurut Satjipto Rahardjo (Satjipto Rahardjo, 2000: 53). 


\section{B. Permasalahan yang dihadapi oleh pihak Bank setelah proses pelaksanaan lelang dilakukan}

Pihak Bank sebagai kreditur yang memiliki hak eksekutorial seharusnya dapat secara langsung mengeksekusi objek Hak Tanggungan sebagaimana diatur dalam Pasal 6 UUHT. Namun demikian, hal yang menarik adalah dalam prakteknya kreditur masih menghadapi berbagai masalah atau kendala ketika hendak mengeksekusi objek Hak Tanggungan yakni seperti debitur yang telah cidera janji atau disebut wanprestasi yang mana debitur dinyatakan wanprestasi apabila debitur tidak melakukan apa yang disanggupi akan dilakukannya; melaksanakan apa yang dijanjikannya, tetapi tidak sebagaimana dijanjikan; melakukan apa yang dijanjikan namun terlambat; melakukan sesuatu yang menurut perjanjian tidak boleh atau dilarang untuk dilakukan.

Walaupun debitur telah wanprestasi, namun masih terdapat debitur yang mengajukan perlawanan atau gugatan atas upaya kreditur untuk mengeksekusi tanah dan bangunan yang dijaminkan, yang kemudian kreditur tetap membutuhkan bantuan Pengadilan untuk mengeksekusi jaminan yang sudah dibebani Hak Tanggungan dimaksud. Hal tersebut juga diatur dalam Pasal 14 Ayat (1) PMK No. 27/PMK.06/2016 yang menyatakan bahwa "apabila adanya gugatan dari pihak tereksekusi atau suami atau istri ataupun pihak lain, maka eksekusi berdasarkan Pasal 6 UUHT tidak dapat dilaksanakan, melainkan harus mengajukan permohonan lelang ke Pengadilan Negeri.” Kendala yang muncul selain adanya gugatan dari pihak debitur atau pihak lain, muncul kendala lain seperti debitur yang tidak bersedia untuk meninggalkan objek Hak Tanggungan ketika kreditur hendak mengeksekusi jaminan tersebut, sehingga kreditur juga harus mengajukan permohonan lelang ke Pengadilan hingga permohonan pengosongan rumah.

Menurut analisa hukum Peneliti, pemberlakuan peraturan tentang adanya hak eksekutorial bagi pihak kreditur tidak memberikan pelindungan hukum kepada kreditur oleh karena walaupun diatur tentang adanya hak eksekutorial untuk kreditur, namun masih terdapat hal-hal dikecualikan seperti eksekusi 
berdasarkan Penetapan Pengadilan apabila adanya gugatan atau adanya perlawanan dari pihak debitur. Berdasarkan hasil wawancara dengan beberapa Bank terkait kendala yang dihadapi dalam eksekusi Hak Tanggungan, Bapak Jumianto, bagian legal dari PT BPR Duta Kepri Tanjungpinang menyatakan bahwa debitur tidak ingin melepas objek Hak Tanggungan untuk dieksekusi melalui proses lelang yang dikarenakan harga dibawah pasaran, namun jika tidak diproses secara langsung, maka tunggakan bunga dan denda akan semakin meningkat yang kemudian akan berpengaruh terhadap tingkat kesehatan Bank itu sendiri. Namun, PT BPR Duta Kepri Tanjungpinang lebih memilih eksekusi Hak Tanggungan melalui proses lelang yang diajukan langsung ke KPKNL dibandingkan permohonan penetapan Pengadilan karena biaya dan waktu yang dibutuhkan akan lebih besar. Selain itu, selama proses Pengadilan berjalan, tunggakan bunga dan denda debitur juga akan tetap berjalan dan merasa sangat dirugikan. Langkah eksekusi Hak Tanggungan yang diambil PT BPR Duta Kepri berbeda dengan PT BPR Satya Mitra Andalan yang mana Peneliti melakukan wawancara dengan Ibu Cindy Indahcahya, bagian legal. Beliau menyatakan bahwa eksekusi Hak Tanggungan melalui proses lelang yang mereka lakukan adalah melalui penetapan Pengadilan dahulu. Hal tersebut dilakukan karena debitur melarikan diri dan tidak dapat ditemukan lagi sehingga PT BPR Satya Mitra Andalan mengambil tindakan demikian meskipun Bank memiliki hak eksekutorial. Jika dapat dihubungi, maka langkah yang ingin diambil oleh PT BPR Satya Mitra Andalan adalah penandatanganan Akta Penyerahan Jaminan dan Akta Kuasa Menjual, namun hal tersebut juga hanya dapat dilakukan apabila debitur bersedia untuk menandatangani Akta-Akta yang bersangkutan (Jumianto: Wawancara, 2020).

Berbeda lagi halnya dengan tindakan yang diambil oleh PT BPR Sejahtera sebagaimana hasil wawancara dengan bagian legal, Hirit Hastari yang menyatakan bahwa apabila debitur cidera janji atau wanprestasi, dan debitur tidak bersedia melakukan penyerahan jaminan, maka pihak Bank akan melakukan penilaian terhadap debitur yang bersangkutan apakah masih memiliki itikad baik dan juga tingkat kesanggupan debitur untuk membayar 
angsuran, yang mana apabila debitur masih dinilai sanggup untuk membayar angsuran maka akan dianjurkan untuk melakukan restrukturisasi. Apabila debitur bersedia menyerahkan jaminan, maka penandatanganan Akta Penyerahan Jaminan dan Akta Kuasa Untuk Menjual akan dilakukan, sehingga pelaksanaan eksekusi Hak Tanggungan melalui proses lelang merupakan jalan alternatif terakhir.

Menurut teori Perlindungan Hukum oleh Satjipto Rahardjo (Satjipto Rahardjo, 2000: 53) yang menyatakan bahwa upaya agar bisa mendapatkan perlindungan hukum yang diinginkan oleh manusia adalah adanya ketertiban dan keteraturan antara nilai dasar dari hukum yakni adanya kepastian hukum, kegunaan hukum serta keadilan hukum. Pemberlakuan Undang-Undang tentang Hak Tanggungan serta Peraturan Pemerintah lainnya yang mengatur tentang eksekusi Hak Tanggungan apabila ditinjau dari teori Perlindungan Hukum, masih belum dapat memberikan kepastian hukum, kegunaan hukum serta keadilan hukum. Menurut Peneliti, kreditur yang telah beritikad baik memberikan pinjaman kepada debitur seharusnya diberikan perlindungan hukum yang lebih maksimal untuk mendapatkan suatu keadilan. Namun berdasarkan hasil wawancara yang telah Peneliti cantumkan diatas, dapat dilihat bahwa eksekusi Hak Tanggungan dilakukan dengan cara yang berbeda-beda sesuai dengan perhitungan dan pertimbangan masing-masing Bank. Cara-cara yang ditempuh oleh Bank memiliki resiko masing-masing yang mana apabila eksekusi Hak Tanggungan dengan cara proses lelang ke KPKNL, peserta lelang yang belum tentu ada sehingga tunggakan bunga dan denda akan tetap berjalan. Apabila dengan cara penandatanganan Akta Penyerahan Jaminan dan Akta Kuasa Untuk Menjual, maka pihak Bank juga harus mencari pembeli atau dapat dibantu oleh pihak lain untuk menjual objek Hak Tanggungan tersebut.

Eksekusi Hak Tanggungan tanpa melalui Penetapan Pengadilan atau pengajuan permohonan lelang secara langsung ke KPKNL tidak menjamin akan terjualnya jaminan debitur tersebut, yang apabila jaminan tersebut tidak berhasil dijual maka akan mengakibatkan kerugian berupa biaya permohonan lelang, waktu yang dihabiskan untuk pengurusan dokumen proses lelang, serta 
penilaian tingkat kesehatan Bank yang akan menurun apabila debitur dalam keadaan menunggak. Apabila eksekusi Hak Tanggungan dilakukan melalui Penetapan Pengadilan, maka biaya serta waktu yang dihabiskan akan bertambah banyak dikarenakan proses yang lebih panjang dibandingkan pengajuan proses lelang secara langsung ke KPKNL. Sebagaimana diketahui bahwa eksekusi Hak Tanggungan melalui Penetapan Pengadilan dilakukan dikarenakan adanya gugatan, perlawanan ataupun debitur yang tidak kooperatif sehingga tindakan untuk mengajukan permohonan lelang ke Pengadilan perlu dilakukan. Selain itu, dalam prakteknya langkah ini dilakukan karena adanya keragu-raguan dari pihak kreditur bahwa akan terjadi permasalahan atau ingin lebih menjamin adanya kepastian hukum. Sebelum mengajukan permohonan lelang ke Pengadilan, kreditur yang dibantu oleh kuasa hukumnya wajib melaksanakan proses dengan cara melayangkan somasi terlebih dahulu sebagaimana Peneliti telah melakukan wawancara dengan salah seorang pengacara yang bekerja sama dengan PT BPR Central Kepri. Beliu menyatakan bahwa somasi dilakukan sebanyak 3x (tiga kali) dengan jangka waktu masing-masing somasi adalah selama 7 (tujuh) hari. Somasi pertama dilayangkan guna untuk memberikan peringatan kepada pihak debitur dengan harapan debitur tetap memiliki itikad baik dan akan melakukan pembayaran angsuran. Namun apabila debitur tidak menanggapi atau tidak membayar angsuran yang telah dirincikan dalam somasi pertama tersebut dalam kurun waktu kurang lebih 7 (tujuh) hari, maka akan dilayangkan somasi kedua kali begitu juga seterusnya. Langkah selanjutnya setelah somasi ketiga tidak ada tanggapan atau itikad baik dari debitur, maka akan dilakukan aanmaning atau panggilan terhadap pihak debitur untuk dapat hadir di Pengadilan sesuai dengan tanggal, hari dan waktu yang telah ditentukan. Apabila debitur tidak hadir, maka akan dilakukan panggilan kedua, hingga panggilan ketiga kalinya. Ketidakhadiran pihak debitur setelah dipanggil sebanyak 3 (tiga) kali, maka akan gugur haknya untuk dipanggil lagi, dan pihak Pengadilan akan mengeluarkan surat penetapan eksekusi kepada Panitera/Jurusita yang kemudian dilanjutkan ke proses pelelangan, yakni ke KPKNL Kota Batam dengan berlandaskan pada Surat Penetapan Pengadilan tersebut. 
Proses lelang dilakukan seperti pada umumnya, dan apabila telah mendapatkan peserta lelang namun debitur masih menempati objek Hak Tanggungan tersebut, maka langkah selanjutnya adalah dengan cara mengajukan permohonan pencabutan sita eksekusi dan pengosongan objek Hak Tanggungan yang wajib dilaksanakan dalam kurun waktu yang telah ditentukan. Proses sebagaimana disebutkan diatas menyebabkan kreditur harus menghabiskan waktu serta biaya yang lebih besar, yang hasilnya tidak menjamin objek Hak Tanggungan akan laku terjual atau akan mendapatkan peserta lelang sehingga mengakibatkan kerugian yang dialami oleh kreditur bertambah banyak. Apabila ditinjau dari teori Perlindungan Hukum oleh Satjipto Rahardjo, peraturan yang berlaku tidak dapat memberikan perlindungan hukum yang maksimal kepada kreditur, sehingga tidak tercapai suatu keadilan bagi kreditur.

\section{Perlindungan hukum bagi peserta lelang yang telah beritikad baik dalam proses lelang ditinjau dari UU No. 4 Tahun 1996 tentang Hak Tanggungan Atas Tanah dan Peraturan Menteri Keuangan No. 27/PMK.06/2016 tentang Petunjuk Pelaksanaan Lelang}

Peneliti menemukan kerugian yang dihadapi oleh peserta lelang yang disebabkan oleh tindakan berupa gugatan dari pihak ketiga, baik dari segi biaya dan juga waktu. Peserta lelang yang seharusnya sudah dapat menikmati objek Hak Tanggungan, menjadi terhambat dan harus mengikuti proses persidangan hingga mendapatkan putusan yang inkracht. UU No. 4 Tahun 1996 serta PMK No. 27/PMK.06/2016 hanya mengatur tentang eksekusi Hak Tanggungan hingga pelaksanaan lelang namun tidak mengatur jika gugatan dari pihak lain dilakukan setelah proses lelang telah dilakukan.

Menurut analisa hukum Peneliti, peserta lelang telah memenuhi unsur kriteria pembeli beritikad baik yang perlindungan hukumnya harus lebih terjamin sebagaimana diatur dalam SEMA No. 4 Tahun 2016 tentang Pemberlakuan Rumusan Hasil Rapat Pleno Kamar Mahkamah Agung Tahun 2016 Sebagai Pedoman Pelaksanaan Tugas Bagi Pengadilan yang diatur dalam 
Rumusan Hukum Perdata terkait kriteria pembeli yang beritikad baik yang perlu dilindungi berdasarkan Pasal 1338 Ayat (3) BW adalah sebagai berikut:

a. "Melakukan jual beli atas objek tanah tersebut dengan tata cara/prosedur dan dokumen yang sah sebagaimana telah ditentukan peraturan Perundangundangan yaitu: a)Pembelian tanah melalui pelelangan umum atau; b) Pembelian tanah dihadapan Pejabat Pembuat Akta Tanah (sesuai dengan ketentuan Peraturan Pemerintah Nomor 24 tahun 1997 atau; c) Pembelian terhadap tanah milik adat / yang belum terdaftar yang dilaksanakan menurut ketentuan hukum adat yaitu: Dilakukan secara tunai dan terang (di hadapan / diketahui Kepala Desa/Lurah setempat) Dan didahului dengan penelitian mengenai status tanah objek jual beli dan berdasarkan penelitian tersebut menunjukkan bahwa tanah objek jual beli adalah milik penjual; d) Pembelian dilakukan dengan harga yang layak".

b. "Melakukan kehati-hatian dengan meneliti hal-hal berkaitan dengan objek tanah yang diperjanjikan antara lain a) Penjual adalah orang yang berhak/memiliki hak atas tanah yang menjadi objek jual beli, sesuai dengan bukti kepemilikannya, atau; b) Tanah/objek yang diperjualbelikan tersebut tidak dalam status disita, atau; c) Tanah objek yang diperjualbelikan tidak dalam status jaminan/Hak Tanggungan, atau; d) Terhadap tanah yang bersertifikat, telah memperoleh keterangan dari BPN dan riwayat hubungan hukum antara tanah tersebut dengan pemegang sertifikat”.

Berdasarkan kriteria yang dirincikan diatas, peserta lelang telah terkategori dalam pembeli beritikad baik yang melakukan proses jual beli objek tanah melalui pelelangan umum yang diajukan oleh pihak kreditur dalam hal ini adalah Bank. Pembeli juga telah mengikuti segala prosedur yang disyaratkan sehingga pembeli dapat dinyatakan sebagai pemenang lelang dan risalah lelang juga telah diterbitkan, sebagaimana berdasarkan hasil wawancara Peneliti dengan Bapak Wismi yang mengurus pendaftaran lelang dari KPKNL Batam, bahwa pembeli yang ingin mendaftarkan diri menjadi peserta lelang dapat dilakukan secara online dengan cara mengakses website https://www.lelangdjkn.kemenkeu.go.id/ yang diawali dengan cara mendaftarkan akun terlebih dahulu, yang kemudian dapat dicari objek lelang yang diinginkan dan mengisi kolom-kolom yang tersedia. Pembayaran jaminan penawaran lelang dilakukan dengan cara transfer ke nomor rekening KPKNL Kota Batam dan akan diakui sebagai peserta lelang. 
Peserta lelang yang telah ditetapkan setelah close biding akan mendapatkan Akta Risalah Lelang yang setara dengan Akta Jual Beli setelah pembayaran PPh dan BPHTB telah dilakukan. Peserta lelang kemudian dapat melakukan proses balik nama sertifikat dengan bantuan Notaris dengan menyerahkan Akta Risalah Lelang, Sertifikat, serta bukti pembayaran pajak PPh dan BPHTB, serta identitas dan dokumen lain yang diperlukan untuk proses balik nama sertifikat. Terkait hal demikian, menurut teori Perlindungan Hukum menurut Satjipto Rahardjo (Satjipto Rahardjo, 2000: 53), peserta lelang seharusnya dilindungi oleh karena permasalahan yang muncul diluar dugaan peserta lelang, yang mana apabila peserta lelang mengetahui akan terjadi hal demikian, peserta lelang yang bersangkutan tidak akan bersedia untuk ikut serta menjadi peserta lelang, sebagaimana berdasarkan hasil responden dari kuisioner yang Peneliti bagikan, sebanyak $85,1 \%$ responden menjawab merasa dirugikan atas proses permohonan pengosongan rumah ke Pengadilan terhadap objek lelang dan atas perihal demikian, sebanyak 51,4\% responden menjadi ragu dan tidak yakin akan menjadi peserta lelang untuk ke depannya, dan sebanyak $27,4 \%$ respon menjawab tidak ingin mengikuti proses jual beli melalui lelang lagi untuk ke depannya. Permasalahan sebagaimana disebutkan diatas tidak menjamin adanya suatu keadilan bagi peserta lelang karena Peraturan Perundang-undangan yang berlaku juga tidak mengatur secara khusus untuk perlindungan hukum bagi peserta lelang.

\section{Penutup}

\section{A. Kesimpulan}

Peneliti mengambil kesimpulan dari penelitian yang dilakukan tentang Pelaksanaan Eksekusi Hak Tanggungan oleh Pihak Bank yakni adalah sebagai berikut:

1. Dalam Pasal 14 Ayat 1 PMK No. 27/PMK.06/2016 telah mengatur secara terperinci tekait pelaksanaan lelang, yang menyatakan bahwa proses lelang yang tidak dapat dilaksanakan berdasarkan Pasal 6 UUHT apabila adanya gugatan dari pihak debitur atau suami atau pihak lain sebelum pelaksanaan 
lelang terhadap objek Hak Tanggungan, melainkan harus melalui Penetapan Pengadilan (Pasal 14 Ayat (3)). Kerugian yang timbul bagi pihak-pihak terkait seperti pihak kreditur dan peserta lelang karena permasalahan hukum yang terjadi diluar dari aturan yang mengatur atau belum diatur dalam Peraturan Perundang-Undangan seperti adanya gugatan dari pihak ketiga setelah proses lelang telah selesai dilaksanakan.

2. Permasalahan yang dihadapi oleh pihak Bank dalam pelaksanaan eksekusi Hak Tanggungan yakni adalah debitur yang tidak dapat diajak untuk kooperatif, debitur yang mengajukan perlawanan atau gugatan ketika pihak Bank hendak melakukan eksekusi Hak Tanggungan, debitur yang tidak ingin mengosongkan objek Hak Tanggungan, sehingga mengakibatkan pihak Bank tidak dapat menggunakan hak eksekutorial berdasarkan Pasal 6 UUHT, melainkan harus mengajukan Penetapan Pengadilan. Pemberlakuan Peraturan Perundang-Undangan yang berkaitan dengan eksekusi Hak Tanggungan masih belum memberikan perlindungan hukum bagi pihak kreditur, dikarenakan masih terdapat pengecualian atas hak eksekutorial yang diberikan kepada pihak kreditur.

3. Perlindungan hukum bagi peserta lelang sebagai pihak pembeli yang telah beritikad baik mengikuti proses lelang masih belum diatur secara rinci dikarenakan yang diatur dalam Undang-Undang Nomor 4 Tahun 1996 tentang Hak Tanggungan serta PMK No. 27/PMK.06/2016 tidak mengatur tentang perlindungan hukum bagi pihak pembeli atau dalam hal ini adalah peserta lelang. Permasalahan yang muncul harus dihadapi oleh peserta lelang dan kerugian yang muncul juga ditanggung sendiri oleh peserta lelang sebagaimana permasalahan tersebut telah terjadi secara nyata yakni putusan No. 92/Pdt.G/2017/PN Btm tanggal 20 Desember 2017.

\section{B. Saran}

1. Pihak Bank dianjurkan untuk dapat lebih hati-hati dalam memilih nasabah yang akan dijadikan sebagai debitur dikarenakan permasalahan atau kendala yang muncul dalam pelaksanaan eksekusi Hak Tanggungan menyebabkan 
kerugian yang lebih besar untuk pihak Bank. Selain itu, pemahaman terhadap Peraturan Perundang-Undangan yang berlaku tentang pelaksanaan Eksekusi Hak Tanggungan khususnya untuk proses lelang juga perlu ditingkatkan agar memudahkan pihak Bank dalam pelaksanaan proses eksekusi Hak Tanggungan.

2. Pengadilan Negeri dan Kantor Pelayanan Kekayaan Negara dan Lelang dianjurkan untuk dapat tetap mempertahankan proses pelaksanaan eksekusi Hak Tanggungan sesuai dengan aturan yang berlaku dan tidak menyimpang agar perlindungan hukum dan keadilan dapat tercapai.

\section{Daftar Pustaka}

Christy, Evie, Wilsen, Dewi Rumaisa, "Kepastian Hukum Hak Preferensi Pemegang Hak Tanggungan dalam Kasus Kepailitan”, Kanun Jurnal Ilmu Hukum, Vol. 22, No. 2, 2020.

Efendi, Jonaedi, Metode Penelitian Hukum Normatif dan Empiris, Jakarta: Prenadamedia Group, 2016.

Jufri, Supriadi, Anwar Borahima, Nurfaidah Said, "Pelaksanaan Lelang Eksekusi Hak Tanggungan Melalui Balai Lelang”, Jurnal Ilmiah Dunia Hukum, Vol. 4, No. 2, 2020.

Rahardjo, Satjipto, Ilmu Hukum, Bandung: Citra Aditya Bakti, 2000.

Sari, Nevita, "Perlindungan Hukum Bagi Konsumen Nasabah Dalam Card Skimming (Studi Kasus Bank Bni Syariah Pusat Di Jakarta)", Reformasi Hukum, Vol. 23, No. 2, 2019.

Republik Indonesia. Undang-Undang Nomor 4 Tahun 1996 Tentang Hak Tanggungan Atas Tanah Beserta Benda-Benda Yang Berkaitan Dengan Tanah. Lembaran Negara Tahun 1996 No.42. Tambahan Lembaran Negara Nomor 3632. , Undang-Undang Nomor 10 Tahun 1998 Tentang Perubahan Atas

Undang-Undang Nomor 7 Tahun 1992 Tentang Perbankan. Lembaran Negara Tahun 1998 No. 182. Tambahan Lembaran Negara Nomor 3790. , Peraturan Menteri Keuangan Nomor 27/PMK.06/2016 tentang Petunjuk Pelaksanaan Lelang, Indonesia. 